\title{
Isolation and Screening of Filamentous Fungi Producing Extracellular Lipase with Potential in Biodiesel Production
}

\author{
Sabrina Moro Villela Pacheco', Américo Cruz Júnior'1, Ayres Ferreira Morgado1, \\ Agenor Furigo Júnior'1, Onyetugo Chioma Amadi², José Manuel Guisán ${ }^{3}$, Benevides Pessela ${ }^{4,5 *}$ \\ ${ }^{1}$ Department of Food and Chemistry Engineering, University Campus UFSC, Florianópolis, Brazil \\ ${ }^{2}$ Department of Microbiology, Faculty of Biological Science, University of Nigeria, Enugu, Nigeria \\ ${ }^{3}$ Departamento de Biocatálises Enzimática, Instituto de Catalisis y Petroleoquimica, ICP (CSIC-UAM), C/Marie \\ Curie 2, Cantoblanco, Campus de la Univerisdad Autónoma de Madrid, Madrid, España \\ ${ }^{4}$ Instituto de Investigación en Ciencias de la Alimentación CIAL (CSIC-UAM), C/Nicolás Cabrera 9, Cantoblanco, \\ Campus de la Universidad Autónoma de Madrid, Madrid, España \\ ${ }^{5}$ Departamento de Engenharia e Tecnologías, Instituto Superior Politécnico de Tecnología e de Ciências, \\ ISPTEC, Luanda Sul, Talatona, República de Angola \\ Email: "b.pessela@csic.es
}

Received 30 September 2015; accepted 18 December 2015; published 21 December 2015

Copyright @ 2015 by authors and Scientific Research Publishing Inc.

This work is licensed under the Creative Commons Attribution International License (CC BY).

http://creativecommons.org/licenses/by/4.0/

(c) (i) Open Access

\begin{abstract}
Nineteen fungal strains were isolated from a chicken slaughterhouse effluent and within those, only one showed high values of lipolytic activity in submerged cultures. This fungus was identified as Trametes hirsuta. The crude extract was immobilized in chitosan/clay beads, with an immobilization yield of $\mathbf{8 0 . 9 \%}$. The analyses of the crude extract and the immobilized derivative at different temperatures, $\mathrm{pH}(\mathrm{s})$, solvents, metallic ions and storage showed that the immobilization process increased the enzyme life span. Ethyl esters were obtained in solvent free systems using chicken viscera oil and the enzyme crude extract. For effective comparison, a reaction using viscera oil and commercial lipase Novozym 435 was carried out. The result revealed $35 \%$ and $28 \%$ esters conversion in the reactions containing chicken viscera oil, using Novozym 435 and the crude extract respectively. The extract was also used in a reaction with soybean oil, traditionally used as starting substrate for biodiesel production.
\end{abstract}

\section{Keywords}

Biodiesel Production, Trametes Hirsuta, Lipase

\footnotetext{
*Corresponding author.
}

How to cite this paper: Pacheco, S.M.V., et al. (2015) Isolation and Screening of Filamentous Fungi Producing Extracellular Lipase with Potential in Biodiesel Production. Advances in Enzyme Research, 3, 101-114. 


\section{Introduction}

The growing concern with the global environmental crisis associated with the use of fossil fuels, and spurred the search for new sources of energy. An interesting alternative to replace fossil fuels is biofuel. The term biofuel refers to liquid or gaseous fuel which is predominantly produced from biomass. Thus, biodiesel is a biofuel comprising a mixture of esters of fatty acids which can be obtained from vegetable oils or animal fats. The production of this biofuel may be performed through a reaction or a transesterification reaction of esterification. The reaction most widely used for the production of biodiesel is the transesterification reaction because it provides one coproduct that has many applications in various industrial segments: glicerol. The enzymes generally used as catalysts of the transterification reactions are lipases [1].

Lipases (triacylglycerol acylhydrolase, EC 3.1.1.3) are hydrolytic enzymes that catalyze the hydrolysis of fats and oils to glycerol and free fatty acids at the oil-water interface. An important characteristic of lipases is their ability not only to hydrolyze ester bonds, transesterify triglycerides, resolve racemic mixtures but also to synthesize ester bonds in nonaqueous media. These enzymes are widely used in hydrolysis, esterification, alcoholysis and transterification catalysts, and are produced by micro-organisms, animals and plants [2]. Commercial lipases are, generally, from microbial sources, with fungi being able to produce the enzyme in a more intense and diversified way, with regard to enzyme properties and substrate specificity, facilitating its use in industrial process. Due to these characteristics, the search for new lipase sources has increased. However, like any other biocatalyst, lipases are subject to inactivation by several chemical, physical and biological factors, which makes its application in a larger scale difficult. One way to reduce this behavior is to immobilize the enzyme [3]. Immobilized enzymes are defined as enzymes that are "physically confined or localized in a certain region with retention of their catalytic activity, enzymes and that can be used several times". Depending on the immobilization technique used, the enzyme properties such as stability, selectivity, values of Vmax, Km, enzymatic activity profile in different pHs and temperatures can be significantly altered [4]. There are several methods for enzyme immobilization based on physical and chemical mechanisms. Among the chemical immobilization methods there are: a) enzyme/support bond through ionic bond; b) enzyme/support bond through covalent bond; c) enzyme/support cross bond and d) enzyme/support bond achieved through multifunctional reactants. The multifunctional reactants are molecules capable of bonding the enzyme in the support, for example, glutaraldehyde [5]. Several kinds of supports with both hydrophilic and hydrophobic characteristics have been studied for enzyme immobilization, including aerogels [6], resin [7], synthetic polymers [7]-[10], silica [11], nanoparticles [12] and biopolymers such as alginate, agarose and chitosan [12]-[14].

Chitosan is obtained through alkaline hydrolysis reaction of chitin, resulting in the biopolymer constituting predominantly of $\beta(1$ - 4)-linked $N$-acetylglucosamine) units, presenting in its chain $70 \%$ - 90\% degree of deacetylation [15]. The use of chitosan in the form of beads is required since it has the advantage of a better superficial characterization, which allows the establishment of geometrical parameters for the reproducibility of the process and further comparisons, also the reactors packing optimization aspects and filtrating devices. Nevertheless, there are disadvantages, such as operational problems regarding the fact that the enzymes density value is very similar to water which can cause flotation. These characteristics limit several industrial processes but can be reduced when chitosan is mixed with solid materials that increase its density and mechanical resistance, this way makes its applications broadened [16]. Among the solid materials that can be used, clay displays outstanding potential, according to the International Association of the Study of Clay and the Clay Minerals Society, it is readily present in nature and constitutes small dimensions minerals which generally exhibit plastic behavior with certain amounts of water and hardens after drying [17].

Hence, in this study, we reported the isolation of a wild fungal strain from chicken slaughterhouse with lipolytic activity, the work further investigated the crude extract potential for posterior immobilization on chitosan/clay beads, characterization of its biochemical properties as well as analysis for application in biodiesel production.

\section{Material and Methods}

\subsection{Source of Microorganisms}

Microorganisms were isolated from a crude effluent of a chicken slaughterhouse located in the region of Florianópolis-Brazil. The effluent used had the following characteristics physico-chemical: $\mathrm{pH}$ 7.3, conductivity of $887.9 \mu \mathrm{S} / \mathrm{cm}$, orthophosphate of $13.2 \mathrm{mg} / \mathrm{l}$, ammonia of $94.7 \mathrm{mg} / \mathrm{l}$, chemical oxygen demand of $2799.4 \mathrm{mg} / \mathrm{l}$, 
biochemical oxygen demand of $4567.7 \mathrm{mg} / \mathrm{l}$ and oils and grease of $901.8 \mathrm{mg} / \mathrm{l}$.

\subsection{Screening}

Microorganisms were isolated using spread plate method. To this, $0.1 \mathrm{ml}$ of the effluent was spread over the surface of the solid culture medium with a Drigalski handle. The culture medium used, Sabouraud agar with Chloramphenicol at a $\mathrm{pH}$ of 5.5, was autoclaved at $121^{\circ} \mathrm{C}$ for $15 \mathrm{~min}$. The Sabouraud agar with Chloramphenicol was obtained from ACUMEDIA. The isolation steps were performed by successive inoculations of fungi in culture media to obtain more axenic selective cultures [18]. The screening of microorganisms with lipolytic activity was carried out in a culture media constituted of (w/v): $2 \%$ bacteriological agar (VETEC), $0.05 \%$ anhydrous calcium chloride (DIFCO), $0.5 \%$ sodium chloride (DIFCO), $1 \%$ bacteriological peptone (DIFCO) and $1 \%$ Tween 80 (VETEC). This method allows detecting the strain that exhibit lipolytic activity by measuring the height of precipitate calcium laurate in test tubes [19]. The height precipitate produced by isolates was comparable with the height produced by strains obtained from the Culture Collections of the Department of Food and Chemistry Engineering (Brazil) that are recognized for producing lipase.

\subsection{Identification of Fungi}

Based on the sequencing and phylogenetic analysis from gene fragments of the operon ribosomal, the fungus was identified [20]. The extracted genomic DNA was performed and amplification of the region ITS1-5.8SITS4 was based on PCR technology. The primers used for amplification of the ITS region were ITS-1 and ITS-4. The fragments were purified and submitted directly sequencing in automatic sequencer ABI3500 XL Series (Applied Biosystem). The phylogenetic analysis of partial sequences of the ITS region, was built on a combination of different obtained fragments and compared with the sequences from organisms represented in the Genbank data base. The sequences were aligned using the CLUSTAL X program and phylogenetic analysis was performed using the MEGA 4.0 software [20]-[22]. The evolutionary distance matrices were calculated using the Kimura model [23] and the construction of the phylogenetic tree based on the evolutionary distances were made by Neighbor-Joining method [24] with bootstrap values calculated from 1000 re-sampling, using MEGA 4.0 software.

\subsection{Preparation of the Crude Extract}

The fungal isolates were inoculated in Roux bottles of $1000 \mathrm{ml}$ with $200 \mathrm{ml}$ of potato dextrose agar medium for 14 days at $25^{\circ} \mathrm{C}$. A $5 \mathrm{ml}$ inoculum was used which was obtained by adding $20 \mathrm{ml}$ of $0.2 \%(\mathrm{v} / \mathrm{v})$ Tween 80 , followed by scraping the surface of the mold with the aid of a platinum loop and filtering gauze. The extracts were obtained by submerged cultivation in flasks of $250 \mathrm{ml}$, using a medium (previously optimized-data not shown) constituting of (w/v in wastewater): $3.41 \%$ of chicken viscera oil (obtained of a chicken slaughterhouse located in the region of Florianópolis-Brazil); $2 \%$ of Tween 80; $\%$ yeast extract (VETEC); $1 \% \mathrm{of}_{\mathrm{NH}_{4} \mathrm{Cl}}$ (NUCLEAR); $0.1 \%$ of $\mathrm{NaNO}_{3}$ (DIFCO); $0.1 \%$ of $\mathrm{KH}_{2} \mathrm{PO}_{4}$ (NUCLEAR); $0.5 \%$ of peptone, $\mathrm{pH} 5.5,0.25 \%$ olive oil (BUNGE), $0.05 \%$ of $\mathrm{MgSO}_{4}$ (NUCLEAR). The flasks were incubated at $25^{\circ} \mathrm{C}, 100 \mathrm{rpm}$ for 10 days, period of time for which it is possible to obtain high values of enzyme activity. The contents of the flask were filtered through gauze to remove the mycelium and centrifuged at $5000 \mathrm{rpm}$ for $5 \mathrm{~min}$. Ammonium sulfate was added to the supernatant at $40 \%$ of saturation. The extract was then maintained by stirring gently at $4^{\circ} \mathrm{C}$ for $240 \mathrm{~min}$. The supernatant was removed and the precipitate was resuspended in a minimal volume (approximately $2 \mathrm{ml}$ ) of 100 $\mathrm{mM}$ phosphate buffer $\mathrm{pH} 7.0$ [25].

\subsection{Immobilization of Enzyme}

Immobilization of the concentrated crude extract was made in beads made of chitosan/clay. The beads were produced through the drip solution of $1 \mathrm{~g}$ of chitosan, $1 \mathrm{~g}$ of clay and $50 \mathrm{ml}$ of acetic acid $1000 \mathrm{mM}$ in $100 \mathrm{mM}$ $\mathrm{NaOH}$ solution. The chitosan used had the following characteristics: average molar mass of $83.7 \mathrm{kDa}$, deacetylation degree of $72.4 \%$ and surface area of $4.9 \mathrm{~m}^{2} / \mathrm{g}$. The smectite clay used was collected from city PalmeiraBrazil and activated with hydrochloric acid to $\mathrm{pH} 4.2$ and humidity of $14.5 \%$ and surface area of $181.4 \mathrm{~m}^{2} / \mathrm{g}$. The beads were activated with 3\% glutaraldehyde (v/v in phosphate buffer $\mathrm{pH} 8.0$ ) for $24 \mathrm{~h}$. 


\subsection{Assay of Enzyme Activity}

The activity of crude extract and immobilized derivative was measured using $0.5 \mathrm{~g}$ of p-nitrophenyl palmitate (p-NPP) (SIGMA) dissolved in $100 \mathrm{ml}$ of ethanol (VETEC) as substrate. The increase in absorbance at $410 \mathrm{~nm}$ caused by the release of p-nitrophenol in the hydrolysis of p-NPP was measured using a spectrophotometer. Crude extract of $0.1 \mathrm{ml}$ (or $0.07 \mathrm{~g}$ immobilized extract) was added to a mixture of $1 \mathrm{ml} 0.5 \%$ (w/v) p-NPP solution and $1 \mathrm{ml}$ buffer Tris-HCl pH 7.0 (SOLARBIO). The system was incubated for $5 \mathrm{~min}$ at $30^{\circ} \mathrm{C}$. The reaction was terminated by adding $2 \mathrm{ml}$ of $0.5 \mathrm{~N} \mathrm{Na}_{2} \mathrm{CO}_{3}$ (VETEC) to the mixture followed by centrifugation $(10,000$ rpm for $10 \mathrm{~min})$. The supernatant $(0.5 \mathrm{ml}$ was diluted 10 times with deionized water and the absorbance at 410 $\mathrm{nm}$ ) was measured (UV-VIS Varian Cary 50 spectrophotometer). A molar extinction coefficient $(\varepsilon 410)$ for p-nitrophenol of $15,000 \mathrm{M}^{-1} \cdot \mathrm{cm}^{-1}$ was used. One unit (U) of lipase activity was defined as the amount of enzyme which catalyzed the production of $1 \mu \mathrm{mol}$ p-nitrophenol per minute under the experimental conditions [26]. The total protein originally taken for immobilization and protein present in the supernatants (unbound protein) after immobilization were estimated by the method of Bradford using BSA as a standard [27]. To obtain the coupled protein percentage value and immobilization yield, calculus described in [28] was used.

\subsection{Effects of Temperature on Stability}

For thermal stability study, the immobilized enzyme and free enzyme was incubated at temperatures between $30^{\circ} \mathrm{C}$ and $70^{\circ} \mathrm{C}$ for $60 \mathrm{~min}$ and relative activity was measured. The enzyme activity was analyzed as described above. Controls were performed with boiled enzyme. The relative enzyme activity was calculated as the ratio of enzyme activity after the incubation period and enzyme activity before the incubation period [29].

\subsection{Effect of $\mathrm{pH}$ on Activity}

Activity experiments were done using the p-NPP method at $30^{\circ} \mathrm{C}$ in experimental mixtures buffered to various $\mathrm{pH}$ values. The following buffers were used: tartrate $\mathrm{pH} 3.0 ; 4.0$ and 5.0; phosphate $\mathrm{pH}$ 6.0, 7.0 and 8.0; Tris-HCl pH 9.0, 10.0 e 11.0 all at $100 \mathrm{mM}$. Controls were performed with boiled enzyme. The final results were presented in terms of relative enzyme activity determined between final enzyme activity (after 5 min incubation with buffer solution) and initial enzyme activity (enzyme activity analyzed immediately after the addition of buffer solution).

\subsection{Stability in Organic Solvents}

A crude extract and immobilized extract was added to a mixture of $50 \%(\mathrm{v} / \mathrm{v}$ in buffer phosphate $\mathrm{pH} 7.0)$. The solvents tested were heptane, hexane, acetone, ethyl ether, methanol, ethanol and chloroform, all purchased from VETEC. The reactions occurring in Erlenmeyer flasks of $250 \mathrm{ml}$ on an orbital shaker conditioned for 6 days at $30^{\circ} \mathrm{C}$ and $100 \mathrm{rpm}$. Aliquots of $1 \mathrm{ml}$ were removed from each flask for enzyme activity analysis after $0,2,4$ and 6 days of incubation. Furthermore, the effect of $3 \%$ glutaraldehyde solution (v/v) on the enzymatic activity of the lipase was also verified under the same conditions described earlier. The results were expressed as relative enzyme activity, using as reference the initial enzyme activity without addition of solvent, in phosphate buffer [30].

\subsection{Effect of Various Substances on Lipase Stability}

The immobilized enzymes were incubated with phosphate buffer $\mathrm{pH}$ 7.0, containing $1 \mathrm{mM}$ of different substances: FeSO4, ZnSO4, NaCl, $\mathrm{CaCl} 2, \mathrm{MnCl} 2, \mathrm{CuSO} 4$ and EDTA. The time of incubation of systems constituted by enzyme and the substances cited above were for $30 \mathrm{~min}$ at $30^{\circ} \mathrm{C}$ [31].

\subsection{Effect of Storage on Lipase Activity}

The stability of the crude extract and immobilized extract enzymatic solution was measured by calculating the relative activity after ten days of storage. $0.1 \mathrm{ml}$ free enzyme and $0.07 \mathrm{~g}$ immobilized enzyme was stored at $12^{\circ} \mathrm{C}$. Enzyme activity analysis was carried out after ten days. The results were presented in terms of relative enzyme activity determined between final enzyme activity, value obtained for enzyme activity after a 10 days incubation 
at $12^{\circ} \mathrm{C}$, and the initial enzyme activity (enzymatic activity analyzed from the moment that the temperature reached $12^{\circ} \mathrm{C}$ ) [32].

\subsection{Lipolytic Activity with Different Substrates}

The reaction media constitutes $1 \mathrm{~g}$ of substrate (Sunflower, Soybean, Castor, Olive and Chicken viscera oil), 0.3 $\mathrm{ml}$ of Tween $80,4 \mathrm{ml}$ of phosphate buffer $(100 \mathrm{mM}), \mathrm{pH}$ 7.0, $0.07 \mathrm{~g}$ of immobilized extract. Then, the system was stirred in orbital shaker for $30 \mathrm{~min}$ at $30^{\circ} \mathrm{C}$ and $150 \mathrm{rpm}$. Aliquots of $8 \mathrm{ml}$ were taken from the reaction media and added to a $50 \mathrm{ml}$ Erlenmeyer flask containing $16 \mathrm{ml}$ of acetone:ethanol 1:1. The activity was measured by titration of the free fatty acids with $\mathrm{NaOH}$ solution $(50 \mathrm{mM})$ using 3 drops of phenolphthalein $1 \%$ as indicator. One unit (U) of enzyme activity was defined as the amount of enzyme which catalyzed the production of 1 $\mu \mathrm{mol}$ of fatty acid per minute under the experimental conditions [31].

\subsection{Reusability of Immobilized Lipase}

The immobilized extract was placed in a test-tube to evaluate the enzyme activity using p-nitrophenyl palmitate. After 5 minutes at $30^{\circ} \mathrm{C}$, the beads were removed through a plastic sieve, washed with a phosphate buffer (100 $\mathrm{mM}$ ), $\mathrm{pH} 7.0$ and put back into the reaction media using the same method. This procedure was repeated five times.

\subsection{Biodiesel Production}

The synthesis of ethylic esters was performed with the use of the crude extract from isolated fungus, Novozym 435, soy oil and chicken viscera oil in $250 \mathrm{ml}$ Erlenmeyers flasks. The chicken viscera oil has the following characteristics: saponification index of $126.42 \mathrm{mg} \mathrm{KOH} / \mathrm{g}$, density of $0.91 \mathrm{~g} / \mathrm{ml}$ and acid index of $2.34 \%$.

Taking into account the average molecular weight of the oils used, it was possible to calculate the mass to be used in reactions to satisfy the molar ratio of 3:1 (alcohol/oil), $1.5 \mathrm{ml}$ of the enzyme solution (Novozym 435 and crude extract) with enzymatic activity of $88.0 \mathrm{U} / \mathrm{ml}$ [33].

The experiments were carried out in an orbital shaker at $30^{\circ} \mathrm{C}, 200 \mathrm{rpm}$ for $24 \mathrm{~h}$. The contents of the Erlenmeyers flasks were added to a separation funnel [34]. A sample of approximately $1 \mathrm{~g}$ of the superior phase, that has the ethylic esters were analyzed through an Gas chromatography coupled mass spectrometry (CG-MS) Shimadzu, Model 2010, column-Restek-RTX Model-5MS. The analysis were performed using a heating ramp was started at $100^{\circ} \mathrm{C}$, with an increase of $8^{\circ} \mathrm{C}$ per minute to $300^{\circ} \mathrm{C}$, obtaining a 10 minutes isotherm. The injector temperature was $280^{\circ} \mathrm{C}$ and with a source interface ion $300^{\circ} \mathrm{C}$, flow divider (split) $1 / 50$. The injection of $1 \mathrm{ml}$ sample was taken in manual mode and the carrier gas used was nitrogen. Were used the following chromatographic standards: ethyl laurate 99\%, myristate acetate 99\%, ethyl oleate 98\% (ALDRICH), ethyl palmitate 99\%, ethyl stearate 99\% and ethyl linoleate 99\% (SIGMA). The identification of chromatographic peaks was performed by comparing with retention times of standards mentioned. The quantification of peaks was performed by normalizing areas. The concentration of each compound was obtained by the chromatograms, which were used to calculate the conversion reaction according to the chemical equation: $1 \mathrm{~mol}$ oil $+3 \mathrm{mols}$ of ethanol $\rightarrow 3$ mols of ester +1 mol of glycerol. To obtain the value of the maximum mass that can be obtained ester was used in Equation (1), where ne is the value related to the maximum number of moles of esters which can be obtained from the reaction $(\mathrm{mol} / \mathrm{l})$, no is the number of moles oil $(\mathrm{mol} / \mathrm{l})$.

$$
\text { ne }=3 * \text { no . }
$$

To obtain the percentage conversion reaction in Equation 2 was used. Where $X$ is the conversion reaction of ethyl esters, $C$ is the mass ethyl ester (g), $M e$ is the maximum mass of esters that can be obtained in the reaction between the oil and the ethanol (g) [35].

$$
X=\frac{C}{M e} .
$$

\section{Results and Discussion}

\subsection{Screening and Preparation of the Crude Extract}

From the slaughterhouse crude effluent was possible to isolate nineteen filamentous fungi strains which were 
classified according to the height of calcium laurate precipitated that is related lipolytic activity from fungal isolates. Through this method was possible to verify that, between the nineteen isolates, only one stood out for lipase activity as illustrated in Table 1. This strain was subjected to cultivation in liquid substrates for analysis of enzyme activity. After a10 day period, high values of enzyme activity of $43.5 \mathrm{U} / \mathrm{ml}$ was obtained. It was observed that the highest enzyme activity values were obtained using a higher concentration of viscera oil, compared to olive oil in the culture medium. This can be attributed to the fact that viscera oil has higher saturated fatty acids. The viscera oil has $30.3 \%$ of saturated fatty acids while olive oil has $20.0 \%$, which indicates that the fungus utilized saturated fatty acids. This same behavior was observed by another author, who studied the production of lipase produced by Geotrichum candidum and found that higher yields were obtained when used to induce the oil that has the greatest percentage of saturated fatty acids [36].

The numbers 1, 2 and 3 that following the parasentes represent proportions of precipitate formed. Based on the tubes with solid culture medium straight, was possible measured with a caliper the formation of the precipitate. Therefore, the number 1 represents the formation of 1 to $2 \mathrm{~cm}$ precipitate. The number 2 represents the formation of 0.7 to $1 \mathrm{~cm}$ precipitate and the number 3 represents is the formation of 0 to $0.7 \mathrm{~cm}$.

Table 1. Screening of fungal strains lipase producers. The symbols $(+++)(++)(+)$ and $(-)$ represent very intense formation of precipitate, mean precipitate formation, little formation of precipitate and no precipitate formation, respectively.

\begin{tabular}{rcc}
\hline Strains tested & Results for lipase production \\
\hline Monascus purpureus (CCT 3802) & $(+) 3$ & $(+) 3$ \\
Rhizopus oryzae (ATCC 9092) & $(+++) 1$ \\
Aspergillus niger & $(++) 2$ \\
Penicillium simplicissimum (CCT 6686) & $(-)$ \\
Isolated 1 & $(-)$ \\
Isolated 2 & $(-)$ \\
Isolated 3 & $(-)$ \\
Isolated 4 & $(-)$ \\
Isolated 5 & $(-)$ \\
Isolated 6 & $(++) 2$ \\
Isolated 7 & $(+) 3$ \\
Isolated 8 & $(-)$ \\
Isolated 9 & $(-)$ \\
Isolated 10 & $(-)$ \\
Isolated 11 & $(-)$ \\
Isolated 12 & $(-)$ \\
Isolated 13 & $(-)$ \\
Isolated 14 & Isolated 15 & $(-)$ \\
Isolated 16 & $(-)$ \\
Isolated 17 & $(-)$ \\
\hline & $(-)$ \\
\hline
\end{tabular}




\subsection{Identification of Fungi}

Fragments of the region ITS from sample was amplified with success. The DNA sequence obtained was analyzed with BLAST from GenBank and CBS (Centraalbureau voor Schimmecultures, Fungal Biodiversity Centre). The phylogenetic tree was built from sample and is illustrated in Figure 1 . The sequence had $100 \%$ identity to Trametes hirsuta. Furthermore, a group formed was supported by a bootstrap of $76 \%$ with the sequence of the species mentioned in Figure 1. Thus, the sample was identified as Trametes hirsuta, which is a basidiomycete white-rot fungus (WRF) that promotes wood decay. The term "white-rot" refers to the wood material after selective degradation of lignin, which leaves the white cellulose exposed. This fungus is traditionally known to produce enzymes that degrade lignin, also known as lacases [36]-[38]. Although this fungus has not been associated with lipase production, it is known that fungi in general, can secrete certain enzymes when stimulated. The fact that the strain was grown in a medium containing high concentrations of fatty acids must have induced lipase production.

\subsection{Enzyme Immobilization}

In this step of the process, the lipase contained in the concentrated crude extract obtained by submerged culture of Trametes hirsuta was immobilized in the chitosan/clay solid support. The support beads were activated using glutaraldehyde and immobilization was performed by direct contact of the enzyme solution with the activated chitosan/clay beads [39]. The percentage of glutaraldehyde solution used to activate the beads is very important as it promotes modification in the spheres geometrical parameters, and is also associated with structural modifications in the enzyme after its activation. The glutaraldehyde molecules bond to the chitosan amine groups, creating an imine group $(\mathrm{CH}=\mathrm{N})$ and, through these groups, the enzyme bonds covalently to the support. However, excess glutaraldehyde molecules on the support's surface may increase the numbers of bonds with the enzyme molecule, leading to a stiffening of the enzyme's tridimensional structure and further loss of biological activity. It is also important to point out that activation of the chitosan/clay beads with glutaraldehyde was carried out in a media with alkaline $\mathrm{pH}$ to favor the imine groups' formation [40]. The formation of such bonds occurs preferentially in alkaline $\mathrm{pH}$, for, in this $\mathrm{pH}$, the amine groups are deprotonated. For the immobilization process, besides the beads activation, their contact with the enzyme solution, enzyme activity analysis and total proteins, both the beads and the supernatant were analyzed to verify if there were any modifications and if, in fact, the crude extract lipase was immobilized. The results revealed that, after 5 hours, $77.4 \%$ of coupled proteins and an immobilization yield of $80.9 \%$ were obtained.

\subsection{Effects of Temperature on Stability}

The thermal stability of enzymes is one of the important criteria for long-term and commercial application. The activity of immobilized enzyme is known to be more resistant against heat than the enzyme in its free state [41]. According to the results obtained as shown in Figure 2, the enzyme in the immobilized extract acquired a higher thermal stability when compared with the enzyme without a support. This difference was observed at temperature of $64^{\circ} \mathrm{C}$ in which the immobilized enzyme was $20 \%$ more active than the unsupported enzyme at the same

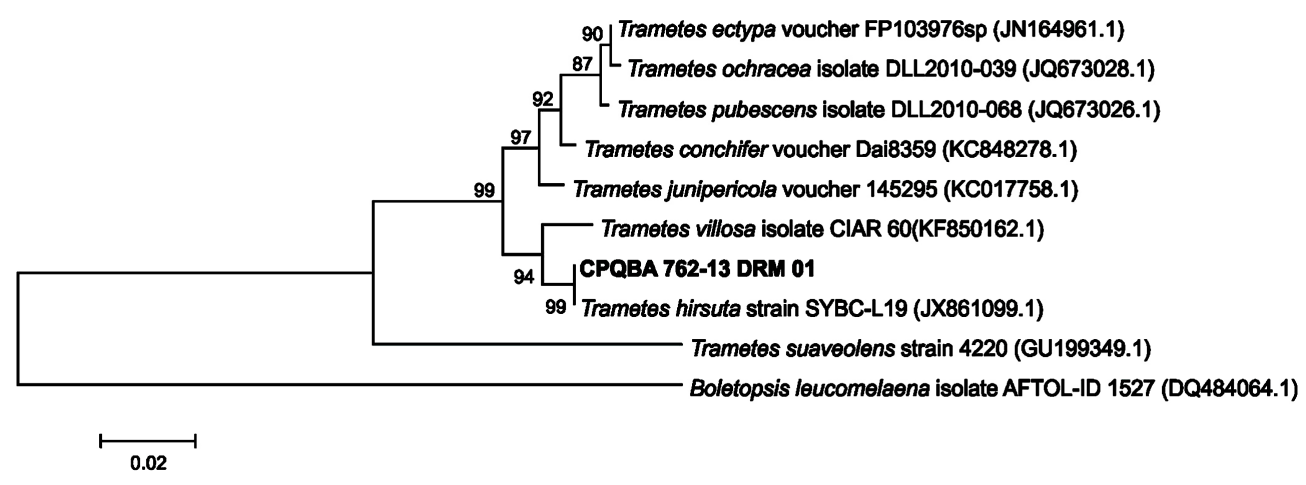

Figure 1. Phylogenetic tree illustrating relationships between the partial sequences of ribosomal genes from isolated fungi and sequences from strains contained in data base GenBank and CBS. 


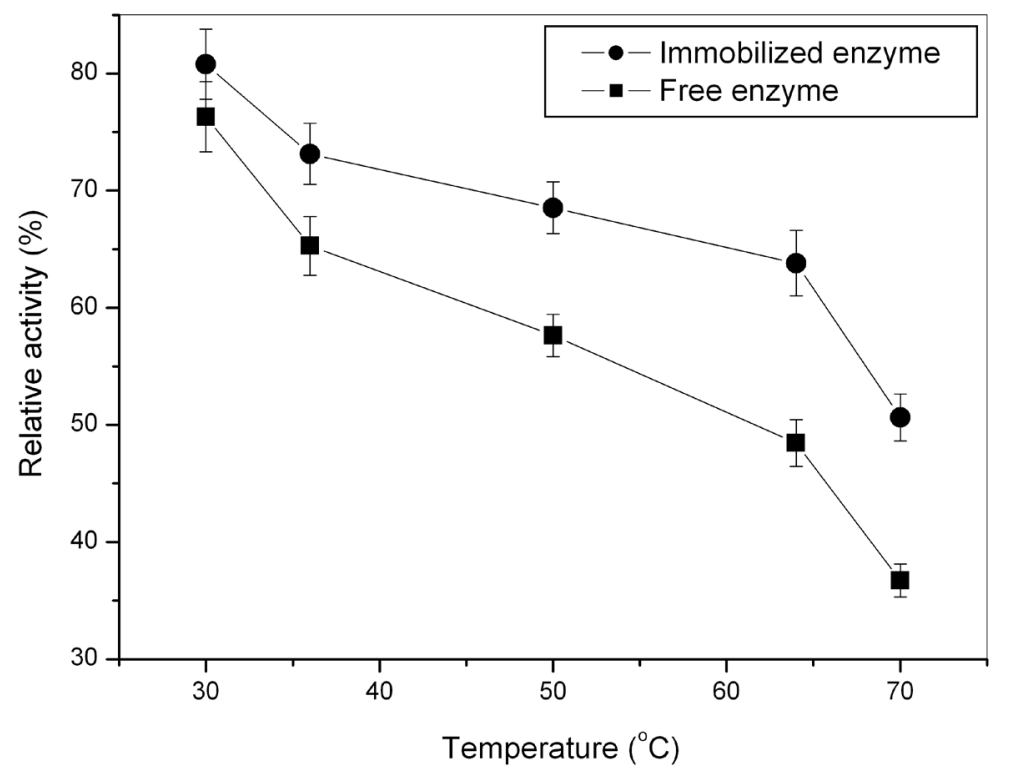

Figure 2. Influence of temperature on lipase activity. Activity was determined at pH 7.0 using p-NNP as substrate. The immobilized enzyme and free enzyme were incubated for $60 \mathrm{~min}$ at the indicated temperatures. Relative activity was assayed at $30^{\circ} \mathrm{C}$ as described above. Relative activity is expressed as percentage of the ratio of the activity after the incubation period and activity before the incubation period determined at $30^{\circ} \mathrm{C}$ under standard conditions.

temperature. At $70^{\circ} \mathrm{C}$ the unsupported enzyme activity was $35 \%$ whereas the immobilized enzyme activity was $50 \%$. Similar behavior of thermal stability was observed in a study that illustrated the biochemical characteristics of Rhizopus oryzae lipase before and after immobilization process [5]. It was also observed when pancreatic lipase was immobilized on the chitosan beads. In this case, the authors observed that the immobilized lipase acquired a much higher thermostability compared to the free enzyme, as when they were incubated for two hours at $50^{\circ} \mathrm{C}$ the immobilized enzyme had a relative activity of $80 \%$, while with the free enzyme there was no activity [42]. This behavior is attributed to interactions between enzyme and support, which often results in a more rigid structure of the protein molecule, giving the globular conformation of the active biocatalyst higher stability to temperature [41].

\subsection{Effect of pH on Activity}

Results obtained as shown in Figure 3, revealed that the immobilization process did not cause modifications in the enzymes optimum $\mathrm{pH}$, since both enzyme forms presented relatively higher enzyme activity values at $\mathrm{pH}$ 7.0. The different enzyme forms exhibited distinctive values of enzyme activity from $\mathrm{pH} 4.0$ to 9.0 ; however, in the $\mathrm{pH}$ zone of 3.0 and 10.0, the enzyme activity values of the two forms were much alike. The fact that $\mathrm{pH} 7.0$ promotes the maximum observed relative activity corroborates with many works quoted in literature that illustrate lipases to present their maximum values of enzyme activity at similar pHs [12] [29] [42].

\subsection{Stability in Organic Solvents}

The stability in organic solvents is an important lipase characteristic and might determine the form in which the enzyme will be utilized, for example, as organic synthesis reaction catalyst. From the results illustrated in Figure 4(a), it was possible to observe that the solvents which led to higher decay of the enzyme activity were ethyl ether, ethanol and acetone. In fact, for these solvents, the enzyme immobilization meant no increase in its life span. A similar behavior was observed in other study, where the authors analyzed the enzyme activity from Rhizopus oryzae lipase in solvents with different polarities and noticed that Acetone led to a higher denaturation rate. This behavior occur due to the lipases low compatibility with hydrophilic solvents, though presenting high compatibility with hydrophobic solvents, since the hydrophobic solvents retain the enzymatic activity by not removing the water molecules of salvation from the enzyme's surface [43]. 


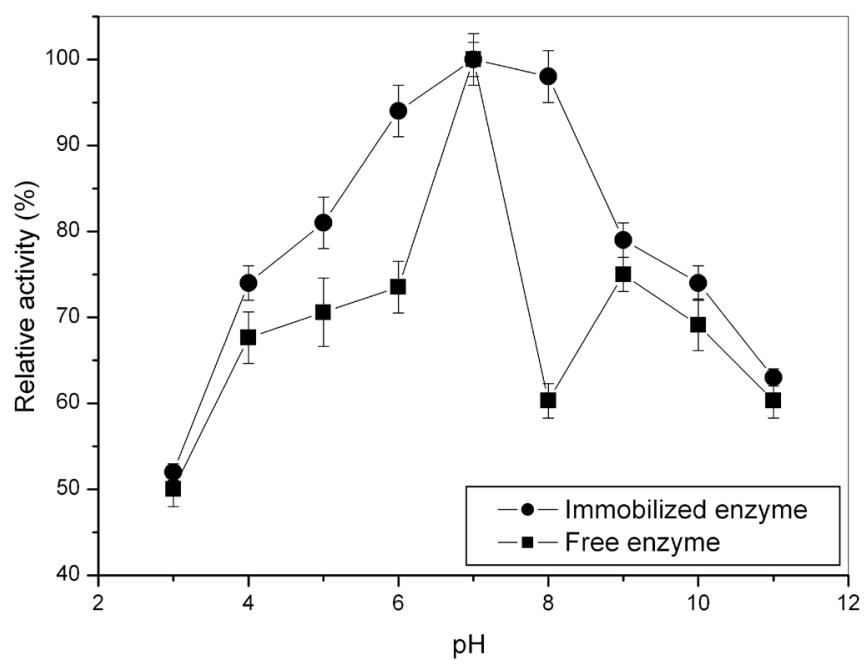

Figure 3. Effect of pH on the activity of the immobilized enzyme and free enzyme. The activity was assayed at various pH values using p-NNP as substrate. The following buffers were used: tartrate ( $\mathrm{pH} 3.0$ - 5.0), phosphate (pH 6.0 - 8.0), Tris-HCl (pH 9.0 - 11.0). The final results were presented in terms of relative enzyme activity as described above.

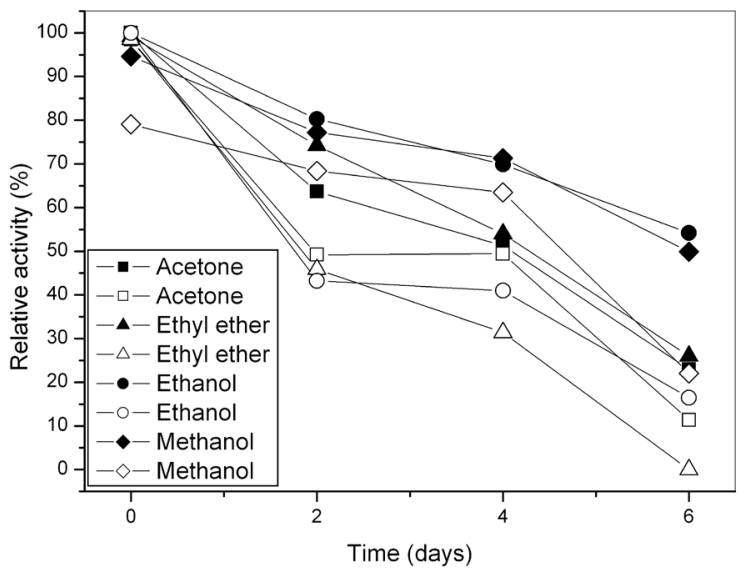

(a)

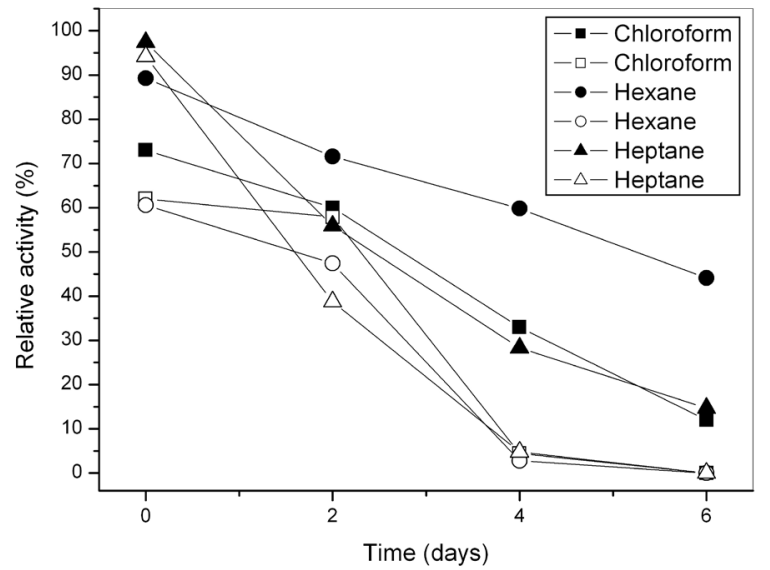

(b)

Figure 4. Effect of different solvents: (a) chloroform, hexane, heptane and (b) acetone, ethyl ether, ethanol, methanol on the activity of the immobilized enzyme and free enzyme. The solvents were tested in mixture of $50 \%$ ( $/ \mathrm{v}$ in buffer phosphate $\mathrm{pH} 7.0$ ) at $25^{\circ} \mathrm{C}$. The enzyme activity was assayed after $0,2,4$ and 6 days of incubation with solvents. The results were expressed as relative enzyme activity, using as reference the initial enzyme activity without addition of solvent, in phosphate buffer. The open symbols represent the free enzyme and the closed symbols represent the immobilized enzyme.

By comparative analysis between hexane and heptane, which have similar values of log $\mathrm{P}$, it was possible to verify that hexane gave more stability to the relative enzyme activity values, even though the initial enzyme activity values with heptane as solvent were higher than with hexane. The initial enzyme activity with heptane was 98\% while hexane showed 91\% enzyme activity, as illustrated in Figure 4(b). This behavior can be explained by the fact that hydrophobic solvents do not lower the activity and can also promote enzymatic activation, since they do not remove water molecules from the enzyme's surface and can interact with the enzyme maintaining the hydrophobic lid open [44]. On the other hand, this argument cannot be applied to all situations, since, in some enzymes, the lid is not necessarily related to the interfacial activation [45].

\subsection{Effect of Various Substances on Lipase Stability}

Salts bring about several effects on proteins properties, including activity, conformational stability and solubility. Such effects possibly appear due to ionic bonds to specific protein sites, changing its hydration level [46]. The 
results obtained for the effect of different ions on the stability of the enzyme obtained in this work are shown in Figure 5. In this work it was possible to verify the effect of enzyme activation when it is exposed to $\mathrm{Fe}^{2+}, \mathrm{Zn}^{2+}$, $\mathrm{Ca}^{2+}$ and $\mathrm{Cu}^{2+}$. This effect was observed by other authors that found high values for enzyme activity after insertion of salts [42] [46]. These features can be associated with structural changes of the enzyme and to the fact that the salts increase the dispersion of enzyme molecules, facilitating mass transfer during the reaction. Other authors [42] observed increase in enzyme activity with the same salts used in this work. However, when there was an increase in the concentration of salts it was observed that there was a decrease in enzyme activity due to the fact that the salt covered the enzyme surface and hindered their contact with the substrate [46]. Furthermore, the EDTA showed an enzymatic inhibitory behavior indicating the importance of the presence of some of those ions for the enzyme activity. This inhibitory effect of the EDTA was also observed in the work by [47] on characterization of lipases from Burkholderia multivorans [48].

\subsection{Effect of Storage on Lipase Activity}

It was observed that the dried immobilized enzyme was the one that exhibited the highest relative enzyme activity of $123 \%$ when compared to the same enzyme in its free form stored at $12^{\circ} \mathrm{C}$, which showed activity of $77 \%$. The results corroborate with the work of [41] that illustrates the study of stability in storage of lipase in its free form and immobilized in chitosan beads, and shows that the lipase in its free form lost all its activity after 2 days of storage at $30^{\circ} \mathrm{C}$. On the other hand, when the same lipase was immobilized in chitosan beads and stored at the same temperature, the complete loss of its activity occurred 4 days after the storage and, when stored without water, the loss occurred only after 8 days of storage [42]. These data showed that the immobilized enzyme stored without any liquids was more stable than the immobilized enzyme stored with water, which indicates that, in aqueous media, the enzyme liberates its support and then denatures.

\subsection{Lipolytic Activity with Different Substrates}

From the data presented in Table 2 it was observed that higher enzyme activities were obtained using, firstly, soybean oil and, secondly, sunflower oil as substrates. The behavior observed can be attributed to the fact that the linoleic acid chain, abundant fatty acids in the soy and sunflower oil, was very adequate for the enzyme active site size and shape. Different substrates bind to the active site of the enzyme, releasing different amounts of energy. This energy is required to promote the necessary changes on the active site and make the most efficient catalyst. In general, substrates with small carbon chains have ability to release small amount of energy to modify the conformation of the lipase. However, substrates with long carbon chains release higher quantities of energy and promote conformational changes more desirable for the reaction [4].

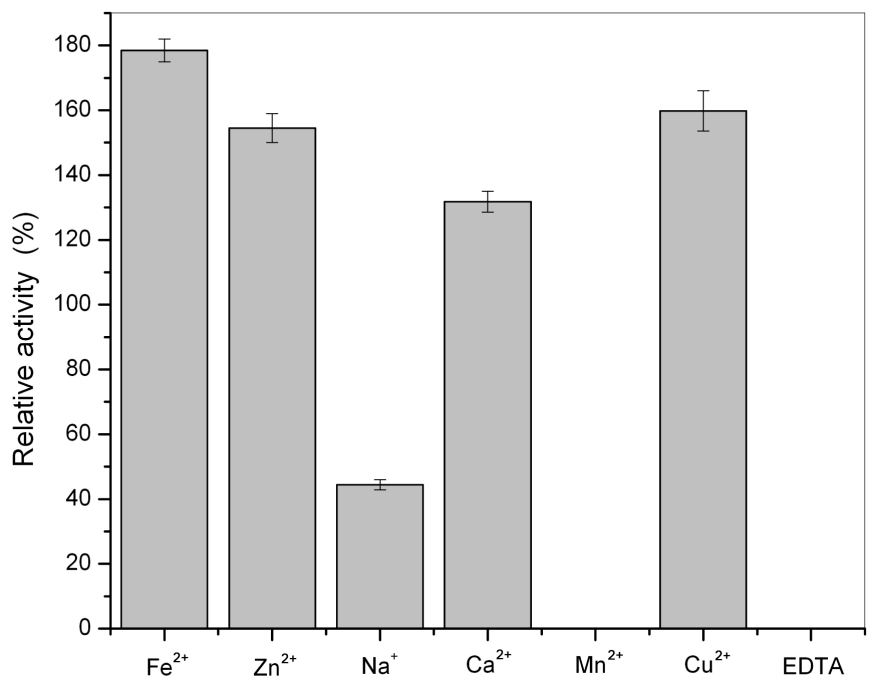

Figure 5. Effects of different substances on the activity of the immobilized enzyme which was incubated with phosphate buffer $\mathrm{pH} 7.0$, containing $1 \mathrm{mM}$ of different substances at $30^{\circ} \mathrm{C}$ for 30 min. Assays were performed in triplicate and mean values were reported. 
Table 2. Effect of different substrates on the hydrolysis activity of the immobilized enzyme. Assays were performed in triplicate and mean values were reported.

\begin{tabular}{cc}
\hline Substrates & Hydrolysis activity (U/ml) \\
\hline Soybean oil & $361 \pm 4.2$ \\
Castor oil & $89 \pm 2.8$ \\
Olive oil & $129 \pm 3.4$ \\
Sunflower oil & $158 \pm 2.7$ \\
Viscera oil & $137 \pm 1.9$ \\
\hline
\end{tabular}

One gramme $(1 \mathrm{~g})$ of substrates was incubated with $0.3 \mathrm{ml}$ of Tween $80,4 \mathrm{ml}$ phosphate buffer $\mathrm{pH} 7.0$ and $0.07 \mathrm{~g}$ of immobilized enzyme, at $30^{\circ} \mathrm{C}$, agitation of $150 \mathrm{rpm}$ for $30 \mathrm{~min}$. Samples of $8 \mathrm{ml}$ were taken and added in a Erlenmeyer flask containing $16 \mathrm{ml}$ of acetone: ethanol 1:1. The activity was measured by titration of the free fatty acids with $\mathrm{NaOH}$ solution $(50 \mathrm{mM})$ using 3 drops of phenolphthalein $1 \%$ as indicator. One unit (U) of enzyme activity was defined as the amount of enzyme which catalyzed the production of $1 \mu \mathrm{mol}$ of fatty acid per minute under the experimental condition. Experiments were performed in triplicate and mean values are reported.

\subsection{Reusability of Immobilized Enzyme}

It was shown that the relative enzyme activity of the immobilized enzyme decayed over its use for hydrolysis reaction using p-NNP as substrate. This behavior was more expressive after the fourth cycle. After five cycles, the relative enzyme activity was $55 \%$. This behavior indicates that the immobilization process resulted in an increased stability for the enzyme. The phenomenon observed can be explained by the fact that there is a possible release of enzyme molecules which eventually become physically bound to the support [42].

\subsection{Biodiesel Production}

This experiment was performed to verify the potential application of the Trametes hirsuta lipase in the production of ethylic esters under specific conditions. The results were compared with a biocatalyst frequently used in several published studies: Novozym 435 [48]-[51]. Chicken viscera oil was the substrate used in this experiment. To perform comparative study widely used starting material, soybean oil was used in the reaction. Ethylic alcohol was the chosen solvent. The experimental conditions for biodiesel production were temperature of $30^{\circ} \mathrm{C}$ for 24 hours. This temperature was chosen after the characterization of the immobilized enzyme had shown that the enzyme showed higher activity at $30^{\circ} \mathrm{C}$. Although many studies have used different experimental conditions for enzyme transterification reaction, generally, the reaction time did not exceed $24 \mathrm{~h}$. In the enzyme transterification, the longer the reaction is carried out, the bigger the conversion rate will be, however a period of $24 \mathrm{~h}$ was used for this study. The results obtained revealed that the experiments using soybean oil with the commercial lipase and with the immobilized enzyme led to the higher values of ester conversion: $90 \%$ and $54 \%$, respectively. The least values were obtained with systems consisting of chicken viscera oil and commercial lipase and chicken viscera oil and immobilized enzyme, which led to activities of 35\% and 28\%, respectively. The behavior observed might be related to the fact that the chicken viscera oil presents different characteristics from the soybean oil, such as the presence of phospholipids, salts, metallic ions and other substances that may affect the final yield. Nevertheless, it is important to highlight that lipase from Trametes hirsuta showed potential in the production of ethylic esters. The optimization of variables that affect directly the transterification reaction such as, water content, molar ratio alcohol-oil, temperature, enzyme concentration and the use of co-solvents will be the future steps in order to obtain better results for these systems.

\section{Conclusion}

It is possible to isolate a filamentous fungus from chicken slaughterhouse effluent, which is capable of producing copious amounts of lipase. This fungus was identified as Trametes hirsuta. Using submerged culture of the isolate, enzyme activity of $43.51 \mathrm{U} / \mathrm{mL}$ was achieved. The crude extract was immobilized in chitosan/clay beads. 
After $5 \mathrm{~h}$ incubation of the concentrated crude extract with the chitosan/clay beads activated with $3 \%(\mathrm{v} / \mathrm{v})$ of glutaraldehyde, an immobilization yield of $80 \%$ was obtained. The crude extract enzyme characterization was performed both in the free and immobilized form. The results showed that the immobilization process allowed the increase of enzyme life span in different temperatures, $\mathrm{pH}(\mathrm{s})$, solvents, metallic ions and storage. The experiments performed to obtain biodiesel and revealed that reasonable values for ester conversion were obtained, thus indicating that the wild lipase and the viscera oil were highly promising substrates for biodiesel production.

\section{Acknowledgements}

The authors thank the academics Joel Pires Viana, Bruna Sampaio Slussarek and Nathália Correa Lima for their support in the experimental activities. CNPq is also gratified for financial support for this research, and CAPEs agency, for Américo Cruz pre doctoral fellowship.

\section{References}

[1] Marchetti, J.M., Miguel, V.U. and Errazu, A.F. (2007) Possible Methods for Biodiesel Production. Renewable and Sustainable Energy Reviews, 11, 1300-1311. http://dx.doi.org/10.1016/j.rser.2005.08.006

[2] Illanes, A. (2008) Enzyme Biocatalysis: Principles and Applications. Springer, Netherlands. http://dx.doi.org/10.1007/978-1-4020-8361-7

[3] Villeneuve, P., Muderhwa, M., Graille, J. and Haas, M. (2000) Customizing Lipases for Biocatalysis: A Survey of Chemical, Physical and Molecular Biological Approaches. Journal of Molecular Catalysis B: Enzymatic, 9, 113-148. http://dx.doi.org/10.1016/S1381-1177(99)00107-1

[4] Tan, T., Lu, J., Nie, K., Deng, L. and Wang, F. (2010) Biodiesel Production with Immobilized Lipase: A Review. Biotechnology Advances, 28, 628-634. http://dx.doi.org/10.1016/j.biotechadv.2010.05.012

[5] Faber, K. (1997) Biotransformations in Organic Chemistry. Springer-Verlag, New York. http://dx.doi.org/10.1007/978-3-662-00431-9

[6] Kharrat, N., Ali, B.A., Marzouk, S., Gargouri, Y. and Châabouni, M.K. (2011) Immobilization of Rhizopus oryzae Lipase on Silica Aerogels by Adsorption: Comparison with the Free Enzyme. Process Biochemistry, 46, 1083-1089. http://dx.doi.org/10.1016/j.procbio.2011.01.029

[7] Minovska, V., Winkelhausen, E. and Kuzmanova, S. (2005) Lipase Immobilized by Different Techniques on Various Support Materials Applied in Oil Hydrolysis. Journal of the Serbian Chemical Society, 70, 609-624. http://dx.doi.org/10.2298/JSC0504609M

[8] Bayramoğlu, G., Kaçar, Y., Denizli, A. and Arıca, M.Y. (2002) Covalent Immobilization of Lipase onto Hydrophobic Group Incorporated Poly(2-Hydroxyethyl Methacrylate) Based Hydrophilic Membrane Matrix. Journal of Food Engineering, 52, 367-374. http://dx.doi.org/10.1016/S0260-8774(01)00128-5

[9] Dave, R. and Madamwar, D. (2006) Esterification in Organic Solvents by Lipase Immobilized in Polymer of PVA-Alginate-Boric Acid. Process Biochemistry, 41, 951-955. http://dx.doi.org/10.1016/j.procbio.2005.10.019

[10] Yong, Y., Bai, Y., Li, Y., Lin, L., Cui, Y. and Xia, C. (2008) Characterization of Candida rugosa Lipase Immobilized onto Magnetic Microspheres with Hydrophilicity. Process Biochemistry, 43, 1179-1185. http://dx.doi.org/10.1016/j.procbio.2008.05.019

[11] Cruz, J.C., Pfromm, P.H. and Rezac, M.E. (2009) Immobilization of Candida antarctica Lipase B on Fumed Silica. Process Biochemistry, 44, 62-69. http://dx.doi.org/10.1016/j.procbio.2008.09.011

[12] Tzialla, A.A., Pavlidis, I.V., Felicissimo, M.P., Rudolf, P., Gournis, D. and Stamatis, H. (2010) Lipase Immobilization on Smectite Nanoclays: Characterization and Application to the Epoxidation of Alfa-Pinene. Bioresource Technology, 101, 1587-1594. http://dx.doi.org/10.1016/j.biortech.2009.10.023

[13] Ting, W.J., Tung, K.Y., Giridhar, R. and Wu, W.T. (2006) Application of Binary Immobilized Candida rugosa Lipase for Hydrolysis of Soybean Oil. Journal of Molecular Catalysis B: Enzymatic, 42, 32-38. http://dx.doi.org/10.1016/j.molcatb.2006.06.009

[14] Foresti, M.L. and Ferreira, M.L. (2007) Chitosan-Immobilized Lipases for the Catalysis of Fatty Acid Esterifications. Enzyme and Microbial Technology, 40, 769-777. http://dx.doi.org/10.1016/j.enzmictec.2006.06.009

[15] Tharanathan, R.N. and Kittur, F.S. (2003) Chitin-The Undisputed Biomolecule of Great Potencial. Critical Reviews in Food Science and Nutrition, 43, 61-87. http://dx.doi.org/10.1080/10408690390826455

[16] Chang, M. and Juang, R. (2004) Stability and Catalytic Kinetics of Acid Phosphatase Immobilized on Composite Beads of Chitosan and Activated Clay. Process Biochemistry, 39, 1087-1091.

http://dx.doi.org/10.1016/S0032-9592(03)00221-8 
[17] Bormans, P. (2004) Ceramics Are More than Clay Alone. Cambridge International Science Publishing, Cambridge.

[18] Freire, D.M., Teles, E.M., Bon, E.P. and Sant'anna Jr., G.L. (1997) Lipase Production by Penicillium restrictum in a Bench-Scale Fermentor: Effect of Carbon and Nitrogen, Agitation and Aeration. Applied Biochemistry and Biotechnology, 63, 409-421. http://dx.doi.org/10.1007/BF02920442

[19] Shelley, A.W., Deeth, H.C. and Macrae, I.C. (1987) Review of Methods of Enumeration, Detection and Isolation of Lipolytic Microorganisms with Special Reference to Dairy. Journal of Microbiological Methods, 6, 127-137. http://dx.doi.org/10.1016/0167-7012(87)90008-X

[20] Raeder, J. and Broda, P. (1985) Rapid Preparation of DNA from Filamentous Fungi. Letters in Applied Microbiology, 1, 17-20. http://dx.doi.org/10.1111/j.1472-765X.1985.tb01479.x

[21] Thompson, J.D., Higgins, D.G., Gibson, T.J. and Clustal, W. (1994) Improving the Sensitivity of Progressive Multiple Alignment through Sequence Weighting, Positions-Specific Gap Penalties and Weight Matrix Choice. Nucleic Acids Research, 22, 4673-4680. http://dx.doi.org/10.1093/nar/22.22.4673

[22] Tamura, K., Dudley, J., Nei, M. and Kumar, S. (2007) MEGA4: Molecular Evolutionary Genetics Analysis (MEGA) Software Version 4.0. Molecular Biology and Evolution, 24, 1549-1599. http://dx.doi.org/10.1093/molbev/msm092

[23] Kimura, M. (1980) A Simple Model for Estimating Evolutionary Rates of Base Substitutions through Comparative Studies of Nucleotide Sequence. Journal of Molecular Evolution, 16, 111-120. http://dx.doi.org/10.1007/BF01731581

[24] Saitou, N. and Nei, M. (1987) The Neighbor-Joining Method for Reconstructing Phylogenetic Trees. Molecular Biology and Evolution, 4, 406-425.

[25] Zeraik, A.E., Souza, F.S., Fatibello-Filho, O. and Leite, O.D. (2008) Desenvolvimento de um Spot Test para Monitoramento da Atividade da Peroxidase em um Procedimento de Purificação. Química Nova, 31, 731-734. http://dx.doi.org/10.1590/S0100-40422008000400003

[26] Chiou, S. and Wu, W. (2004) Immobilization of Candida rugosa Lipase on Chitosan with Activation of the Hydroxyl Groups. Biomaterials, 25, 197-204. http://dx.doi.org/10.1016/S0142-9612(03)00482-4

[27] Bradford, M.M. (1976) A Rapid and Sensitive Method for the Quantification of Microgram Quantities of Protein Dye Binding. Analytical Biochemistry, 72, 248-254. http://dx.doi.org/10.1016/0003-2697(76)90527-3

[28] Hung, T., Giridhar, R., Chiou, S. and Wu, W. (2003) Binary Immobilization of Candida rugosa Lipase on Chitosan. Journal of Molecular Catalysis B: Enzymatic, 26, 69-78. http://dx.doi.org/10.1016/S1381-1177(03)00167-X

[29] Abbas, H., Hiol, A., Deyris, V. and Comeau, L.C. (2002) Isolation and Characterization of an Extracellular Lipase from Mucor sp. Strain Isolated from Palm Fruit. Enzyme and Microbial Technology, 31, 968-975. http://dx.doi.org/10.1016/S0141-0229(02)00190-4

[30] Kamini, N.R., Fujii, T., Kurosu, T. and Iefuji, H. (2000) Production, Purification and Characterization of an Extracellular Lipase from the Yeast, Cryptococcus sp. S-2. Process Biochemistry, 36, 317-324. http://dx.doi.org/10.1016/S0032-9592(00)00228-4

[31] Pastore, G.M., Costa, V.S.R. and Koblitz, M.G.B. (2003) Production, Partial Purification and Biochemical Characterization of a Novell Rhizopus sp. Strain Lipase. Food Science and Technology, 23, 135-140. http://dx.doi.org/10.1590/S0101-20612003000200006

[32] Wang, D., Xu, Y. and Shan, T. (2008) Effects of Oils-Related Substrates on the Synthetic Activity of MembraneBound Lipase from Rhizopus chinensis and Optimization of the Lipase Fermentation Media. Biochemical Engineering Journal, 41, 30-37. http://dx.doi.org/10.1016/j.bej.2008.03.003

[33] Lopes, C.R., D’oca, C.D.R.M., Duarte, R.C., Kurz, M.H.S., Primel, E.G., Clementin, R.M., Villarreyes, J.A.M. and D’oca, M.G.M. (2010) Síntese de novas amidas graxas a partir da aminólise de ésteres metílicos. Química Nova, 33, 1335-1341. http://dx.doi.org/10.1590/S0100-40422010000600022

[34] Tashtoush, G.M., Al-Widyan, M.I. and Al-Jarrah, M.M. (2004) Experimental Study on Evaluation and Optimization of Conversion of Waste Animal Fat into Biodiesel. Energy Conversion and Management, 45, 2697-2711. http://dx.doi.org/10.1016/j.enconman.2003.12.009

[35] Faccio, C., Rosa, C.D., Amroginski, C., Bender, J.P., Lipke, N., Oliveira, D., Oliveira, J.V., Luccio, M. and Dariva, C. (2005) Optimization of Alkaline Transesterification of Soybean Oil and Castor Oil for Biodiesel Production. Applied Biochemistry and Biotechnology, 122, 553-560. http://dx.doi.org/10.1385/ABAB:122:1-3:0553

[36] Burkert, J.F.M., Maugeri, F. and Rodrigues, M.I. (2004) Optimization of Extracellular Lipase Production by Geotrichum sp Using Factorial Desing. Bioresource Technology, 91, 77-84. http://dx.doi.org/10.1016/S0960-8524(03)00152-4

[37] Chaurasia, P.K., Yadav, R.S.S. and Yadava, S. (2014) Purification and Characterization of Yellow Laccase from Trametes hirsuta MTCC-1171 and Its Application in Synthesis of Aromatic Aldehydes. Process Biochemistry, 49, 16471655. http://dx.doi.org/10.1016/j.procbio.2014.06.016 
[38] Couto, S.R. (2007) Decolouration of Industrial Azo Dyes by Crude Laccase from Trametes hirsuta. Journal of Hazardous Materials, 148, 768-770. http://dx.doi.org/10.1016/j.jhazmat.2007.06.123

[39] Jiang, D., Long, S., Huang, J., Xiao, H. and Zhou, J. (2005) Immobilization of Pycnoporus sanguineus Laccase on Magnetic Chitosan Microspheres. Biochemical Engineering Journal, 25, 15-23. http://dx.doi.org/10.1016/j.bej.2005.03.007

[40] Morrison, R. and Boyd, R. (1996) Química Orgânica. Fundação Calouste Gulbenkian, Lisboa.

[41] Guisan, J.M. (2013) Immobilization of Enzymes and Cells. Third Edition, Methods in Molecular Biology, Vol. 1051, Humana Press, Totowa. http://link.springer.com/book/10.1007\%2F978-1-62703-550-7 http://dx.doi.org/10.1007/978-1-62703-550-7

[42] Desai, P.D., Dave, A.M. and Devi, S. (2006) Alcoholysis of Salicornia Oil Using Free and Covalently Bound Lipase onto Chitosan Beads. Food Chemistry, 95, 193-199. http://dx.doi.org/10.1016/j.foodchem.2004.12.030

[43] Essamri, M., Deyris, V. and Comeau, L. (1998) Optimization of Lipase Production by Rhizopus oryzae and Study on Stability of Lipase Activity in Organic Solvents. Journal of Biotechnology, 60, 97-103. http://dx.doi.org/10.1016/s0168-1656(97)00193-4

[44] Klibanov, A.M. (1997) Why Are Enzymes Less Active in Organic Solvents than in Water? Trends in Biotechnology, 15, 97-101. http://dx.doi.org/10.1016/s0167-7799(97)01013-5

[45] Verger, R. (1997) Interfacial Activation of Lipases: Facts and Artifacts. Trends in Biotechnology, 15, 32-38. http://dx.doi.org/10.1016/S0167-7799(96)10064-0

[46] Yu, H.W., Chen, H., Yang, Y.Y. and Ching, C.B. (2005) Effect of Salts on Activity, Stability and Enantioselectivity of Candida rugosa Lipase in Isooctane. Journal of Molecular Catalysis B: Enzymatic, 35, 28-32. http://dx.doi.org/10.1016/j.molcatb.2005.05.002

[47] Demir, B.S. and Tukel, S.S. (2010) Purification and Characterization of Lipase from Spirulina platensis. Journal of Molecular Catalysis B: Enzymatic, 64, 123-128. http://dx.doi.org/10.1016/j.molcatb.2009.09.011

[48] Dandavate, V., Jinjala, J., Keharia, H. and Madamwar, D. (2009) Production, Partial Purification and Characterization of Organic Solvent Tolerant Lipase from Burkholderia multivorans V2 and Its Application for Ester Synthesis. Bioresource Technology, 100, 3374-3381. http://dx.doi.org/10.1016/j.biortech.2009.02.011

[49] Mittelbach, M. (1990) Lipase Catalysed Alcoholysis of Sunflower Oil. Journal of the American Chemical Society, 67, 168-169.

[50] Rodrigues, R.C., Volpato, G., Wada, K. and Ayub, M. (2008) Enzymatic Synthesis of Biodiesel from Transesterification Reactions of Vegetable Oils and Short Chain Alcohols. Journal of the American Oil Chemists' Society, 85, 925930. http://dx.doi.org/10.1007/s11746-008-1284-0

[51] Maceiras, R., Vega, M., Costa, C., Ramos, P. and Márquez, M.C. (2009) Effect of Methanol Content on Enzymatic Production of Biodiesel from Waste Frying Oil. Fuel, 88, 2130-2134. http://dx.doi.org/10.1016/j.fuel.2009.05.007 